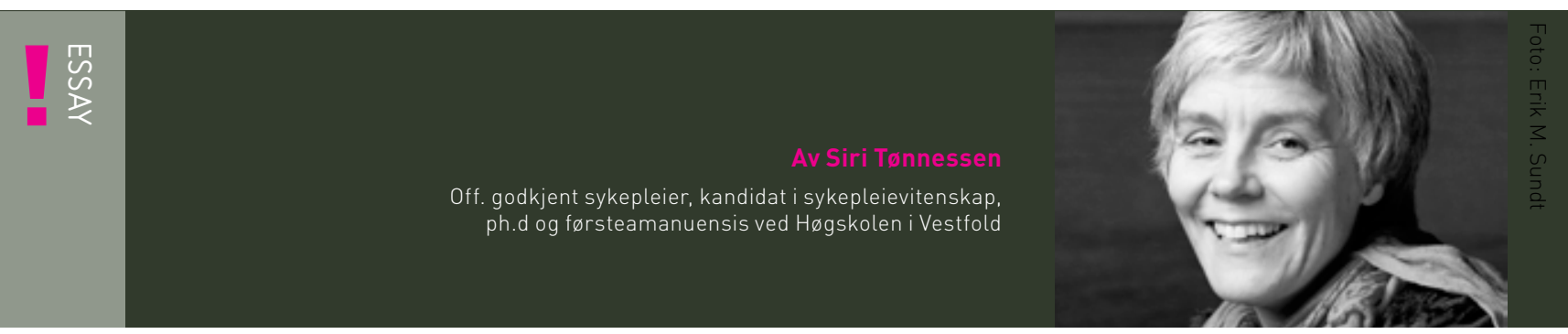

\title{
Faglige forutsetninger for forsvarlighetsbegrepet
}

\author{
$>$ I en vurdering av om tjenester er sykepleiefaglig forsvarlige \\ er det avgjørende hvilke kriterier man legger til grunn.
}

I samarbeid med Per Nortvedt har jeg tidligere presentert tre krav til faglig forsvarlige tjenester i hjemmesykepleien knyttet til gjeldende lovverk om kommunale helse- og omsorgstjenester (1). Det er imidlertid avgjørende hvilke hensyn disse kriteriene bygger på. Hensikten i dette essayet er å utdype hvilke forutsetninger et forsvarlighetsbegrep i sykepleien må bygge på, samt å avklare hvilke faglige hensyn som må ligge til grunn. Målet er å gjøre sykepleieperspektivet tydelig.

\section{HVORFOR ER DET VIKTIG?}

En tydeliggjøring av sykepleieperspektivet i et forsvarlighetsbegrep i sykepleie er viktig, fordi undersøkelser (2-5) og rapporter fra Helsetilsynet (6-7) viser at kvaliteten i pleie- og omsorgstjenestene ikke er tilfredsstillende. I helsetjenesten er det et misforhold mellom de oppgaver og tjenester kommunene er pålagt å yte og de ressursene de har til rådighet $(3,8-9)$. For sykepleierne innebærer dette daglig vanskelige prioriteringer, der grensene for hva som oppleves som god fagutøvelse utfordres
(10-13). Pasientene sykepleierne skal ivareta er syke og har et redusert funksjonsnivå enten fysisk og/ eller mentalt. De trenger pleie og omsorg på mange ulike måter, fra veiledning, støtte og hjelp i forbindelse med dagliglivets aktiviteter, medisinsk behandling, til lindring og trøst fordi de er ensomme eller nærmer seg livets sluttfase. Mange sykepleiere, spesielt i kommunehelsetjenesten, beskriver at det er en daglig utfordring å sikre pasientene de tjenestene de har behov for $(3,13)$. For at pasientene skal få forsvarlige tjenester og for å bidra til faglig refleksjon og bevisstgjøring er det derfor presserende å avklare det sykepleiefaglige grunnlaget for et forsvarlighetsbegrep i sykepleie.

\section{HVA ER GALT I DAG?}

I vurderingen av om en tjeneste er sykepleiefaglig forsvarlig har juridiske aspekter hatt en framtredende rolle. Samtidig har kravet om omsorgsfull hjelp vært lite vektlagt. Statens helsetilsyn, som har til oppgave å følge med i om forsvarlighetskravet oppfylles av helsetjenesten, legger sterk vekt på juridiske og medisinske kriterier (14). Prinsippene helsetilsynet legger til grunn for «Utredning og vurdering av faglig forsvarlighet i klinisk praksis» er tilpasset normer for medisinsk behandling, og ikke andre deler av helsetjenesten, som for eksempel kravet til god sykepleie $(15,16)$. Forsvarlighetskravet i helselovgivningen beskrives som en rettslig standard for hva som er forsvarlig medisinsk behandling (17-19). Det mangler en diskusjon om hva som skal være innholdet i sykepleiefaglige forsvarlighetskriterier og hvilke faglige forutsetninger som må ligge til grunn for et forsvarlighetsbegrep i sykepleie (20). Skal forsvarlighetsbegrepet i sykepleie bli tydelig må det «frigjøres» fra det juridiske og medisinske forsvarlighetsbegrepet, fordi disse begrepene bygger på andre hensyn og forutsetninger enn det som er sentralt for sykepleie. Et forsvarlighetsbegrep i sykepleie må bygge på et fundament som er sentralt for sykepleiefaget. Det innebærer at fagets normer, verdier, funksjon og ansvar må ligge til grunn. 


\section{Fagets normer, verdier, funksjon \\ og ansvar må ligge til grunn.}

\section{SYKEPLEIEPERSPEKTIVET}

\section{Hensyn på individnivå}

Sykepleie er å yte omsorgsfull hjelp med bakgrunn i teoretisk, etisk og erfaringsbasert kunnskap og kompetanse i det konkrete møtet med den enkelte pasient (21-23). Forsvarlighetsbegrepet i sykepleie må derfor handle om relasjonen mellom pasient og sykepleier på individnivå, basert på pasientens behov for tjenester i situasjonen. Offentlige pleie- og omsorgstjenester tildeles ved juridiske enkeltvedtak som er personlige og individuelle vedtak $(24,25)$. Det innebærer at et forsvarlighetsbegrep i sykepleie må omhandle noen krav til hvilke tjenester pasientene skal få dekket av det offentlige, og hvordan sykepleieren skal ivareta disse tjenestene i møte med pasienten. Kravene må imidlertid være i tråd med sykepleiefaglige normer og verdier $(1,3)$.

\section{Faglige normer og verdier}

Forsvarlighetskravet i utøvelse av sykepleie dreier seg om å beskytte pasientene mot handlinger som ikke er i tråd med normer for faglig forsvarlig praksis (26). Forsvarlighetsbegrepet i sykepleie må derfor bygge på faglige kunnskaper om pasientenes grunnleggende pleie- og omsorgsbehov og sentrale verdier i sykepleie (27). Den juridiske og medisinske forsvarlighetsnormen knyttes til hvor alvorlig de medisinske konsekvensene er, og overskrides først når det er fare for liv og helse.

Forsvarlighetsbegrepet i sykepleie må imidlertid omfatte noe mer enn det medisinske og juridiske forsvarlighetsbegrepet hvis det skal være i tråd med sykepleiefaglige normer og verdier. Forsvarlighetsbegrepet i sykepleie må både knyttes til en faglig akseptabel minstestandard for grunnleggende pleie- og omsorgstjenester, og til menneskeverdet. Det vil si verdirasjonelle handlinger som gjør livet levelig for den syke her og nå. Uforsvarlighet vil være ikke å handle i tråd med forsvarlighetsnormen, for eksempel ved å unnlate å utføre handlinger pasientene har krav på (26). Det innebærer at forsvarlighetsnormen i sykepleie overskrides når basale fysiologiske, psykososiale og åndelige behov ikke ivaretas, eller når verdier som respekt og verdighet krenkes. I praksis betyr det at en pasient som får hjelp til å få dekket sitt behov for mat og drikke, både må sikres tilstrekkelig næringsinntak, men også oppleve seg sett og ivaretatt i situasjonen. Det betyr at sykepleierne må ha tid til å spørre pasienten hva slags mat han kan tenke seg å spise og tilrettelegge måltidet slik at pasienten får lyst til å spise. Hvis pasienten har dårlig matlyst og trenger sosialt fellesskap for å få i seg maten, må sykepleieren ha tid til å sette seg ned å påse at maten blir spist. Sykepleierne må ha tid til samtale og støtte når pasienten føler seg ensom og tid til trøst når pasienter sørger. Det er særlig knyttet til pasientenes psykososiale behov at tjenestene ikke er forsvarlige i dag $(1-3,6)$.

Samtidig er faglig forsvarlighet ikke et statisk begrep, men en minstenorm for praksis som forandrer seg over tid $(19,28)$. God sykepleiepraksis refererer ofte til en standard som ligger over forsvarlighetskravet (26). Det er imidlertid uklart hvilken standard som gjelder for god sykepleiepraksis. Slik jeg ser det vil det være vanskelig å skille god praksis fra hva som er faglig forsvarlig. Det er fordi forsvarlige tjenester begrunnet i menneskeverdet må ta hensyn til hva pasienten opplever som god ivaretakelse. Det innebærer at et forsvarlighetskrav i sykepleie også må handle om god praksis. Pasienter kan imidlertid ha ulike oppfatninger av hva som er godt. Det som defineres som god sykepleiepraksis hos en pasient vil være forskjellig og kunne endres. Det innebærer at et forsvarlighetsbegrep i sykepleie må legge til grunn verdier som ivaretar fleksibiliteten i relasjonen mellom sykepleier og pasient samt vise til en minstestandard for det som ansees som akseptabel faglig praksis (29).

\section{Sykepleiens fundament}

I sykepleie er omsorgsfull ivaretakelse av pasientene selve fundamentet faget bygger på $(21,23,30)$. En sykepleier kan ikke handle forsvarlig uten å være omsorgsfull.Samtidig krever det å yte omsorgsfull hjelp faglige kunnskaper og innsikt. Et eksempel er hvordan en sykepleier hjelper en pleietrengende med å ivareta personlig hygiene. Hjelp til vask og stell kan være krenkende hvis det ikke gjøres både med faglig innsikt om kropp, sykdom og 


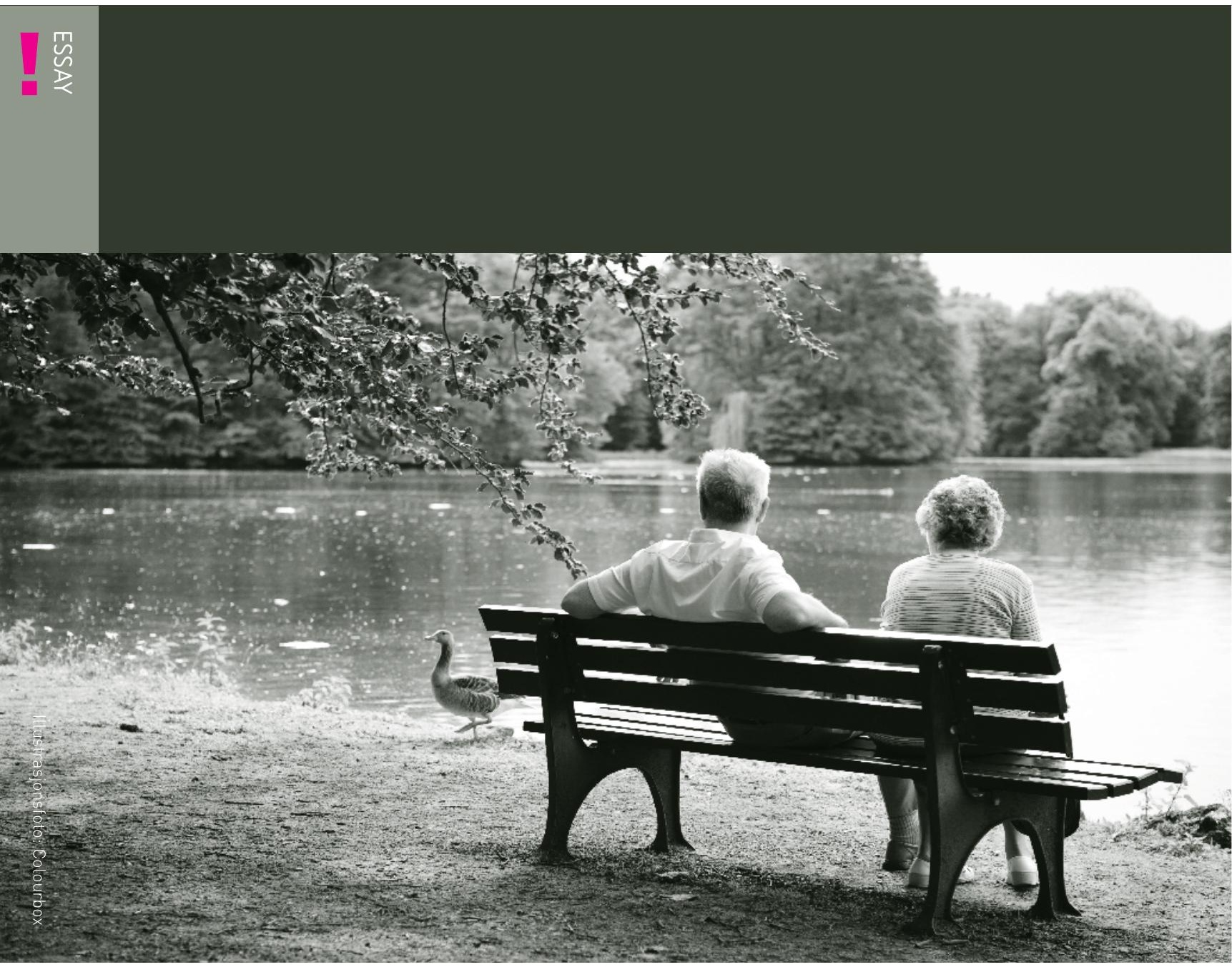

funksjon, og med holdninger og varhet som ivaretar pasientens integritet. Skal sykepleieutøvelsen være faglig forsvarlig, må bluferdighet og respekt ivaretas slik at pasienten opplever tjenesten som omsorgsfull $(19,31,32)$. Samtidig må omsorgen som ytes bygge på faglig kunnskap om hygiene og etikk slik at pasientens behov ivaretas forsvarlig. Dette innebærer at omsorgsbegrepet og omsorgsfull hjelp må være et bærende perspektiv for forsvarlighetsbegrepet i sykepleien. I praksis betyr det for eksempel at når en pasient sitter ved vasken for å få hjelp til morgenstell må hygieniske prinsipper, som å vaske fra reint til ureint, følges når avfallsstoffer fjernes.
En omsorgsfull ivaretakelse, og dermed også forsvarlige tjenester, innebærer imidlertid også et godt håndlag. Det vil si at kluten må være passe våt og varm og holdes på en slik måte at pasienten opplever det godt å bli vasket og at huden ikke skrapes opp. Samtidig må sykepleieren være høflig og oppmerksom i situasjonen slik at pasientens grenser ikke blir krenket. Det kan innebære at pasienten skal få være alene på badet og vaske seg selv hvis han vil og klarer det.

\section{Hensikt og ansvar}

Forsvarlighetsbegrepet i sykepleie må bygge på hensyn som er relevante for den funksjonen sykepleierne har og den omsor- gen sykepleieren skal yte. Det innebærer at begrepet må være i tråd med det som er sykepleierens ansvar og sykepleietjenestens hensikt. En sykepleier skal ivareta grunnleggende behov og daglige tjenester som pasientene ikke har krefter, kunnskaper eller vilje til å klare selv $(33,34)$. Det kan være å hjelpe pasientene med konkrete gjøremål, «gjøre for» pasientene, gi veiledning og støtte slik at pasienten kan ivareta behovene selv, eller ved tilstedeværelse og oppmerksomhet i møtet med vanskelige livssituasjoner. Sykepleietjenestens hensikt og sykepleierens ansvar er på denne måten sentrale hensyn for et forsvarlighetsbegrep i sykepleie. 


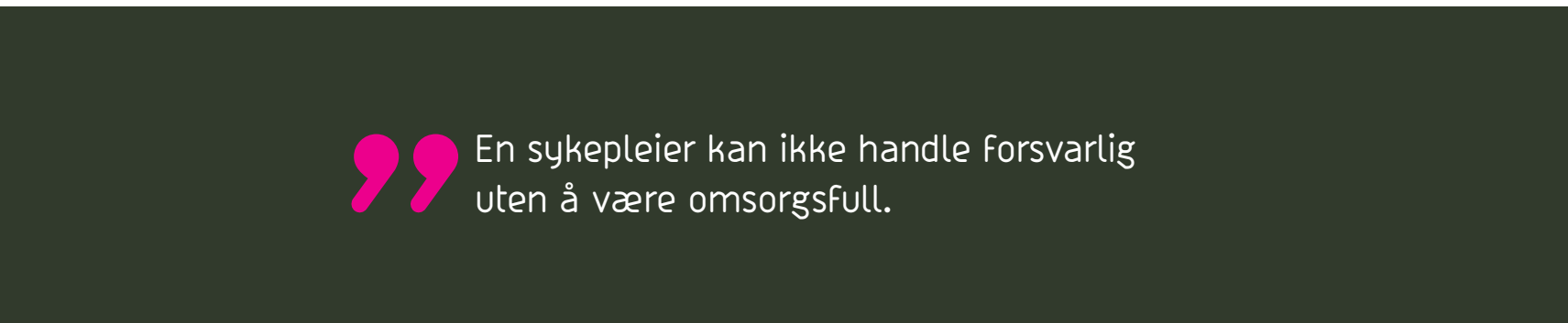

\section{AVSLUTNING}

Det er en forutsetning at et forsvarlighetsbegrep i sykepleie må bygge på hensyn som er relevante for sykepleiefaget. Jeg har argumentert for at relevante faglige hensyn handler om hensyn på individnivå, faglige normer og verdier, at omsorgsbegrepet er bærende og at sykepleiens hensikt og ansvar må legges til grunn. Jeg mener at en utdyping av hvilke faglige hensyn et forsvarlighetsbegrep i sykepleie må bygge på er en forutsetning for å gjøre sykepleieperspektivet tydelig.

\section{REFERANSER}

1. Tønnessen S, Nortvedt P. Hva er faglig forsvarlig hjemmesykepleie? Sykepleien forskning. 2012;7:280-5

2. Tønnessen S, Førde R, Nortvedt P. Pasientenes beskrivelser av hjemmesykepleien når ressursene er begrenset, Omsorg på andres premisser. Nordisk Tidsskrift for Helseforskning. 2009;5:57-71.

3. Tønnessen S. The Challenge To Provide Sound and Diligent Care - a qualitative study of nurses' decisions about prioritization and patients' experiences of the home nursing service. Doktorgradsavhandling. University of Oslo. Oslo. 2011. 4. Thorsen K, Værness K (red.) Blir omsorgen borte? Eldreomsorgens hverdag i den senmoderne velferdsstaten. Ad Notam Gyldendal. Oslo. 1999.

5. Vabø M. Organisering for velferd. Hjemmetjenesten i en styringsideologisk brytningstid. NOVA. Oslo. 2007.

6. Statens helsetilsyn. Pleie- og omsorgstjenester på strekk: sammenstilling og analyse av funn og erfaringer fra ulike tilsynsaktiviteter i 2003 og 2004. Helsetilsynet. Oslo. 2005.

7. Statens helsetilsyn. Et Stykkevis og delt tjenestetilbud?: oppsummering av landsomfattende tilsyn 2005 med kommunale helse- og sosialtjenester til voksne personer over 18 år med langvarige og sammensatte behov for tjenester. Statens helsetilsyn. Oslo. 2006.
8. Østerud $\emptyset$, Engelstad F, Selle P. Makten og demokratiet: en sluttbok fra Maktog demokratiutredningen. Gyldendal akademisk. Oslo. 2003.

9. Vike H, Hauklien H. Velferdspolitikk ved reisens slutt. Norsk Sykepleierforbund. Oslo. 2007.

10. Vabø M. Hva er nok? Om behovsfortolkninger i hjemmetjenesten. NOVA. Oslo. 1998.

11. Nortvedt $P$, Pedersen $R$, Grothe $K H$, Nordhaug M, Kirkevold M, Slettebo A, et al. Clinical prioritisations of healthcare for the aged-professional roles. J Med Ethics. 2008;34(5): 332-5.

12. Tønnessen S, Førde R, Nortvedt P. Fair Nursing Care When Resources Are Limited: The Role of Patients and Family Members in Norwegian Home-Based Services. Policy, Politics, \& Nursing Practice. 2009;10:276-84.

13. Tønnessen S, Nortvedt P, Førde R. Rationing home-based nursing care professional ethical implications. Nursing Ethics. 2011;18:386-96.

14. Lov om statlig tilsyn med helse- og omsorgstjenestene m.m. 30 mars 1984; nr. 15 [Helsetilsynsloven]. Tilgjengelig fra: http://www.lovdata.com/cgi-wift/ wiftloksok? base $=Q N L \&$ sys $=1 \&$ felt $=$ titt \&emne $=$ statlig+tilsyn \&PROS $=02$ (Nedlastet 06.01.2012).

15. Statens helsetilsyn. Veileder for sakkyndig uttalelse i tilsynssaker til Statens helsetilsyn og Helsetilsynet i fylkene. Statens helsetilsyn. Oslo. 2010

16. Statens helsetilsyn. Utredning og vurdering av faglig forsvarlighet i klinisk praksis. Statens helsetilsyn. Oslo. 2010. 17. Halvorsen M. «Nødvendig helsehjelp" »som redskap for prioriteringer. Lov og Rett. 2004;3:143-56.

18. Kjønstad A. Helserett - pasienters og helsearbeideres rettsstilling. 1 ed. Gyldendal Norsk Forlag. Oslo. 2005.

19. Molven 0. Kravet til helsepersonell og virksomheter i helsetjenesten om forsvarlighet. Lov og Rett. 2009;48:3-26. 20. Molven 0. Sykepleie og jus. 1 ed. Gyldendal Norsk Forlag AS. Oslo. 2006.

21. Nortvedt P. Sykepleiens grunnlag: historie, fag og etikk. Universitetsforlaget. Oslo. 2008.

22. Martinsen K. Fra Marx til Løgstrup: om etikk og sanselighet i sykepleien. TANO. Oslo. 1993.

23. Martinsen K, Eriksson K. A se og å innse: om ulike former for evidens.
Akribe. Oslo. 2009.

24. Lov om behandlingsmåten i forvaltningssaker 2 oktober 1967. [Forvaltningsloven]. Tilgjengelig fra: http://lovdata. no/cgi-wift/wiftldles? doc=/app/gratis/ www/docroot/all/nl-19670210-000. html\&emne=FORVALTNINGSLOV*\& \& . (Nedlastet 06.01.2012)

25. Lov om kommunale helse- og omsorgstjenester m.m. 24 juni 2011; nr. 30 [Helse- og omsorgstjenesteloven]. Tilgjengelig fra: http://lovdata. no/cgi-wift/wiftldles? doc=/app/gratis/www/docroot/all/nl-20110624030.html\&emne=KOMMUNALE*\%20 $\% 2$ b\%20HELSE*\%20 \%2b\%200G*\%20 $\% 2 \mathrm{~b} \% 200 M S O R G S T J E N E S T E R * \& \&$. (Nedlastet 06.01.2012).

26. Norsk Sykepleierforbund. Det du bør vite om Faglig Forsvarlighet. Norsk Sykepleierforbund. Oslo. 2008.

27. Norsk Sykepleierforbund. Yrkesetiske retningslinjer for sykepleiere: ICNs etiske regler. Norsk Sykepleierforbund. Oslo. 2007.

28. Molven 0. Helse og Jus, En innføring for helsepersonell. 6 ed. Gyldendal Norsk Forlag AS. Oslo. 2009.

29. Kjønstad A. Helserett - pasienters og helsearbeideres rettsstilling. 1 ed. Gyldendal Norsk Forlag. Oslo. 2005.

30. Martinsen K. Omsorg, sykepleie og medisin: historisk-filosofiske essays. TANO. Oslo. 1989

31. Braut GS. Fagleg forsvarleg verksemd handlar om gode prosessar. Tidsskrift for Den norske legeforening. 2008:19.

32. Braut GS, Vist jr. J. Faglig forsvarlighet-garanti og grense. In: Torgauten T-I. (red.). Utviklingshemming og tros-og livssybsutøvelse Rettigheter og tilrettelegging. Universitetsforlaget. Oslo. 2010. 33. Henderson V. Basic principles of nursing care. International Council of Nursing. Geneva. 1997

34. Forskrift om kvalitet i pleie og omsorgstjenestene for tjenesteyting etter lov av 19. november $1982 \mathrm{nr}$. 66 om helsetjenesten i kommunene og etter lov av 13. desember $1991 \mathrm{nr} .81$ om sosiale tjenester m.v. 27 juni 2003; nr. 792. Tilgjengelig fra: http://Lovdata. no/cgi-wift/wiftldles? doc=/app/gratis/ www/docroot/for/sf/ho/ho-20030627$0792 . h t m l \&$ emne=KVALITET*\%20 $\% 2 \mathrm{~b} \% 20$ l* $\% 20 \quad \% 2 \mathrm{~b} \% 20$ PLEIE*\%20 $\% 2 \mathrm{~b} \% 200 \mathrm{G} \% 20 \% 2 \mathrm{~b} \% 200 M$ MORGSTJENEST*\&\&. (Nedlastet 06.01.2012) 